2do. Seminario Nacional de Enfermedad Renal Crónica de Causa no Tradicional (ERCnT) en Guatemala 2nd National Seminar on Chronic Kidney Disease of Unknown Cause (CKDu) in Guatemala

\title{
Caracterización de factores sociodemográficos, epidemiológicos y clínicos de pacientes masculinos con ERCnT en la Unidad Nacional de Atención al Enfermo Renal Crónico
}

\author{
Characterization of sociodemographic, epidemiological and clinical factors of male patients \\ with CKDu at the National Unit for Chronic Kidney Disease Care
María C. Figueroa*1, Josué C. Zárate ${ }^{1}$, María F. González${ }^{1}$, José A. Solis, Brenda N. Acabal ${ }^{1}$, Naara González ${ }^{1}$, Janira N. Acajabón ${ }^{1}$, Cindy A. Oliva ${ }^{1}$, Julio Boj², Karla Lange¹, Gerardo Arroyo ${ }^{1}$
${ }^{1}$ Escuela de Química Biológica, Facultad de Ciencias Químicas y Farmacia, Universidad de San Carlos de Guatemala y ${ }^{2}$ Unidad Nacional de Atención al Enfermo Renal Crónico (Unaerc), Guatemala,

\begin{abstract}
*Autor al que se dirige la correspondencia: lauradavila197@gmail.com
\end{abstract}
\section{Resumen}

$\mathrm{L}$ a ERCnT es un daño funcional del riñón que no está asociada con una historia de diabetes ni hipertensión, con una disminución de la tasa de filtración glomerular por debajo de $60 \mathrm{~mL} / \mathrm{min} / 1.73 \mathrm{~m}^{2}$, cuya causa aún no ha sido claramente establecida. El objetivo de esta investigación fue la caracterización de pacientes de sexo masculino con ERCnT que están siendo atendidos en la Unidad Nacional de Atención al Enfermo Renal Crónico (Unaerc), para lo cual se realizó un estudio de tipo descriptivo, transversal. La muestra la constituyó 83 pacientes de sexo masculino, en donde se analizaron variables sociodemográficas, epidemiológica y clínicas. Para recolectar los datos se utilizó la técnica de entrevista. Para analizar las variables obtenidas se aplicó estadística descriptiva, analizando la información mediante tablas de distribución de frecuencia y porcentaje. Se obtuvo que en factores sociodemográficos la mayoría de pacientes que padecen ERCnT provenían de los departamentos de Jutiapa, Jalapa y Escuintla, que la mayoría era de raza ladina, con vivienda de block y que indican tener acceso a los servicios básicos de agua, luz y extracción de basura. En factores epidemiológicos predominan pacientes con edades entre 18-28 años, agricultores con largas jornadas de trabajo expuestos al sol, que consumían bebidas carbonatadas y alcohólicas. En factores clínicos la mayoría no presenta antecedentes familiares de enfermedad renal.

Palabras claves: Pesticidas, altas temperaturas, consumo de tabaco, nivel de ingresos

\section{Abstract}

$\mathrm{C}$ $\mathrm{KDu}$, is a functional kidney damage, which is not associated with a history of diabetes or hypertension, with a decrease in glomerular filtration rate below $60 \mathrm{~mL} / \mathrm{min} / 1.73 \mathrm{~m}^{2}$, which cause has not yet been clearly established. The objective of this research was the characterization of male patients with ERCT that are being treated at the National Unit for Chronic Kidney Disease Care (Unaerc). A descriptive, cross-sectional, study was conducted. The sample was 83 male patients, from which sociodemographic, epidemiological and clinical variables were analyzed. To collect the data, an interview was conducted. To analyze the variables, descriptive statistics were used, analyzing the information with frequency and percentage distribution tables. It was obtained that in sociodemographic factors that the majority of patients suffering from CKDu were from the departments of Jutiapa, Jalapa and Escuintla, that the majority were of Ladino ethnicity with building block housing and that indicated to have access to the basic services of water, light and garbage extraction. Epidemiological factors predominate in patients aged 18-28 years, farmers with long working hours exposed to high temperatures, who consumed carbonated drinks and alcoholic beverages. In clinical factors most patients didnot have a family history of kidney disease. 